\title{
Radioiodine therapy in elderly patients with subclinical hyperthyroidism due to non- voluminous nodular goiter and its effect on bone metabolism
}

\author{
Terapia com radioiodo em pacientes idosos com \\ hipertireoidismo subclínico por bócio nodular não \\ volumoso e efeito sobre o metabolismo ósseo
}

Pedro Weslley Rosario ${ }^{1,2}$

1 Postgraduation Program, Santa Casa de Belo Horizonte, Belo Horizonte, MG, Brazil

${ }^{2}$ Endocrinology Service, Santa Casa de Belo Horizonte, Belo Horizonte, MG, Brazil
Correspondence to: Pedro Weslley Rosario Instituto de Ensino e Pesquisa, Santa Casa de Belo Horizonte Rua Domingos Vieira, 590 30150-240 - Belo Horizonte, MG, Brazil

pedrorosario@globo.com

Received on Sept/30/2012 Accepted on Nov/12/2012

\begin{abstract}
Objective: To evaluate ${ }^{131}$ | therapy in elderly patients with subclinical hyperthyroidism (SCH) due to nodular disease and who did not receive antithyroid drugs (ATDs), and the effect of the treatment on bone metabolism. Subjects and methods: Thirty-six patients with TSH $\leq 0.1 \mathrm{mIU} / \mathrm{L}$ and non-voluminous goiter $\left(<60 \mathrm{~cm}^{3}\right)$ were studied. Bone mineral density (BMD) was assessed in 17 women with osteopenia. Results: Mean 24-h ${ }^{131}$ I uptake was $17.5 \%$. Symptoms of thyrotoxicosis were reported by two $(5.5 \%)$ patients in the first week after therapy. One year after radioiodine treatment, $\mathrm{SCH}$ was resolved in $30(83.3 \%)$ patients, and hypothyroidism was detected in one $(2.7 \%)$. In the patients in whom TSH returned to normal, femoral and lumbar spine BMD increased by $1.9 \%$ and $1.6 \%$, respectively, in average. Conclusions: In elderly patients with $\mathrm{SCH}$ and non-voluminous goiter, radioiodine not preceded by ATDs is a safe and effective therapeutic alternative. Resolution of $\mathrm{SCH}$ has beneficial effects on BMD in postmenopausal women with osteopenia. Arq Bras Endocrinol Metab. 2013;57(2):144-7
\end{abstract}

Keywords

Subclinical hyperthyroidism; radioiodine; nodular disease

\section{RESUMO}

Objetivo: Avaliar a terapia com ${ }^{131} \mathrm{I}$ em idosos com hipertireoidismo subclínico (HSC) por doença nodular que não receberam drogas antitireoidianas (DATs) e o efeito no metabolismo ósseo. Sujeitos e métodos: Trinta e seis pacientes com TSH $\leq 0,1 \mathrm{mUI} / \mathrm{L}$ e bócio não volumoso $\left(<60 \mathrm{~cm}^{3}\right)$ foram estudados. Dezessete mulheres com osteopenia foram submetidas à avaliação da densidade mineral óssea (DMO). Resultados: Captação média de ${ }^{131}$ l em 24 h foi 17,5\%. Sintomas de tireotoxicose foram reportados por dois pacientes $(5,5 \%)$ na primeira semana após a terapia. Um ano após o radioiodo, HSC foi resolvido em 30 pacientes $(83,3 \%)$ e hipotireoidismo ocorreu em 1 (2,7\%). Nas pacientes que normalizaram oTSH, DMO em fêmur e coluna lombar incrementou em média 1,9\% e 1,6\%, respectivamente. Conclusões: Em idosos com HSC e bócio não volumoso, radioiodo, não precedido de DATs, é uma alternativa terapêutica segura e eficaz. Resolução do HSC tem benefício na DMO em mulheres menopausadas com osteopenia. Arq Bras Endocrinol Metab. 2013;57(2):144-7

Descritores

Hipertireoidismo subclínico; radioiodo; doença nodular 


\section{INTRODUCTION}

A lthough controversy exists regarding the indications for treatment of subclinical hyperthyroidism $(\mathrm{SCH})$, there is consensus that therapy is necessary in elderly patients with $\mathrm{TSH} \leq 0.1 \mathrm{mIU} / \mathrm{L}$ (1). In this age group, $\mathrm{SCH}$ is almost always caused by nodular disease (2). Radioiodine therapy is an excellent option for patients with a contraindication to or who refuse surgery; it is also an alternative to thyroidectomy in patients with non-voluminous goiter without compressive symptoms or suspicion of malignancy (1). If ${ }^{131} \mathrm{I}$ is administered in the presence of undetectable levels of TSH, normal thyroid tissue does not take up, or takes up very little radioiodine, reducing the risk of hypothyroidism $(3,4)$. In addition, the chance of success (resolution of hyperthyroidism) may be greater in patients who did not receive antithyroid drugs (ATDs) before the administration of ${ }^{131} \mathrm{I}(5)$. On the other hand, treatment with ATDs reduces the risk of acute exacerbation of thyrotoxicosis (5), which is a matter of concern, particularly in older patients.

One of the repercussions of $\mathrm{SCH}$ is a decline of bone mineral density (BMD), notably in postmenopausal women and in patients with TSH $\leq 0.1 \mathrm{mIU} / \mathrm{L}$ $(1,6)$. However, few studies have evaluated the effect of treatment of SCH on bone metabolism and bone mass (7-9).

We report here our experience with ${ }^{131} \mathrm{I}$ therapy in elderly patients with $\mathrm{SCH}(\mathrm{TSH} \leq 0.1 \mathrm{mIU} / \mathrm{L})$ due to non-voluminous nodular goiter who did not receive ATDs prior to radioiodine administration. In addition, we evaluated the effect of this treatment on bone turnover and BMD in women with osteopenia.

\section{SUBJECTS AND METHODS}

Thirty-six patients (24 with multinodular disease and 12 with uninodular disease; 29 women, age: 66 to 80 years) were studied. SCH was diagnosed when TSH was $\leq 0.1 \mathrm{mIU} / \mathrm{L}$ in two measurements obtained at a 3-month interval, associated with normal free T4 and total T3 levels. Autonomous nodular disease was diagnosed based on the demonstration of one or more accumulating areas upon ${ }^{131}$ I scintigraphy and suppression of the remaining parenchyma. None of the patients presented compressive symptoms due to voluminous goiter.

For the treatment with ${ }^{131} \mathrm{I}$, it was ensured that patients had not used amiodarone or had been recently ex- posed to iodinated contrast. In addition, patients were asked to consume a low-iodine diet 7 days prior to therapy. Patients who had been treated with ATDs, those prepared with recombinant human TSH (rhTSH), or those previously undergoing ${ }^{131} \mathrm{I}$ treatment were excluded from the study. All patients received $50 \mathrm{mg} /$ day atenolol from the first week before ${ }^{131} \mathrm{I}$ administration until normalization of TSH. A fixed activity of 15 $\mathrm{mCi}{ }^{131} \mathrm{I}$ was administered. Higher ${ }^{131} \mathrm{I}$ activities were not used since the group mainly consisted of women $(80 \%)$ older than 40 years with non-voluminous goiter and mild hyperthyroidism, all predictors of a better response to radioiodine treatment (10).

Patients were asked to report symptoms of thyrotoxicosis (11) when they occurred, and were also asked about the presence of symptoms 2 and 7 days after ${ }^{131} \mathrm{I}$ therapy. TSH, free T4 and total T3 were measured one week, and 1, 3, 6, 9, and 12 months after radioiodine administration. L-T4 therapy was introduced if TSH > $10 \mathrm{mIU} / \mathrm{L}$ in the presence of low free T4, or if TSH continued to be $>10 \mathrm{mIU} / \mathrm{L}$ in two measurements, even when free T4 was normal. ATDs were indicated only if TSH was undetectable and free T4 or total T3 was elevated one month after treatment, or if TSH continued to be undetectable and free T4 and total T3 were normal one year after therapy. Patients were classified one year after radioiodine administration as shown in table 1 .

Table 1. Classification of the patients one year after radioiodine therapy

\begin{tabular}{|c|c|}
\hline Status & Definiton \\
\hline Euthyroidism & TSH of 0.4 to $4 \mathrm{mlU} / \mathrm{L}$ without treatment* \\
\hline Subclinical hypothyroidism & $\begin{array}{l}\text { TSH of } 4 \text { to } 10 \mathrm{mlU} / \mathrm{L} \text { (normal free T4) without } \\
\text { treatment }^{\star}\end{array}$ \\
\hline Hypothyroidism & Treatment with L-T4 \\
\hline Subclinical hyperthyroidism & $\begin{array}{l}\mathrm{TSH}<0.4 \mathrm{mlU} / \mathrm{L} \text { (normal free T4 and total T3) } \\
\text { without treatment* }\end{array}$ \\
\hline Hyperthyroidism & Treatment with ATDs \\
\hline
\end{tabular}

ATD: antithyroid drug. * Use of L-T4 or ATD.

For the evaluation of the benefit of $\mathrm{SCH}$ treatment, a subgroup of 17 women was studied. These women had osteopenia [no history of fractures and lumbar and/or femoral BMD - 1 to -2.5 standard deviations of the young adult mean (T-score)], normal serum PTH and no vitamin D deficiency $[25(\mathrm{OH})$ vitamin D $>20 \mathrm{ng} / \mathrm{mL}(12,13)$ in all patients and $>30 \mathrm{ng} / \mathrm{dL}$ in 14 women], and did not use estrogens, corticosteroids, antiresorptive agents or bone-building drugs. These 
patients were submitted to the assessment of BMD, serum carboxyterminal telopeptide (CTx), and osteocalcin before, and one year after radioiodine treatment.

The study was approved by the Ethics Committee of the institution.

TSH, free T4, total T3 and PTH were measured with a chemiluminescent assay with reference values of 0.4-4 mIU/L, 0.8-2.0 ng/dL, 80-180 ng/dL, and $12-65 \mathrm{pg} / \mathrm{mL}$, respectively. CTx and osteocalcin were measured by an electrochemiluminescence assay, with reference values of 0.104 to $1.008 \mathrm{ng} / \mathrm{mL}$ (postmenopause), and 12 to $46 \mathrm{ng} / \mathrm{mL}$, respectively. High-performance liquid chromatography was used for the measurement of $25(\mathrm{OH})$ vitamin $\mathrm{D}$.

BMD was measured by dual energy $x$-ray absorptiometry (DEXA) in the femoral neck and lumbar spine (Ll-L4). Scintigraphy was carried out 24 hours after the administration of $100-300 \mu \mathrm{Ci}{ }^{131} \mathrm{I}$. Sonography was performed with a linear multifrequency 10-12 $\mathrm{MHz}$ transducer for morphological analysis (B-mode).

The two-tailed unpaired Student $t$-test and MannWhitney $\mathrm{U}$ test were used for statistical analysis. P-value less than 0.05 was considered to be significant.

\section{RESULTS}

In the 12 patients with uninodular disease, the volume of the nodule estimated by ultrasound ranged from 3.6 to $20 \mathrm{~cm}^{3}$, and total gland volume ranged from 12.5 to $32.1 \mathrm{~cm}^{3}$. Uptake of ${ }^{131} \mathrm{I}$ in the $24^{\text {th }}$ hour ranged from $11.5 \%$ to $32.1 \%$ (mean: $18.7 \%$ ). In the 24 patients with multinodular disease, thyroid volume ranged from 28 to $58 \mathrm{~cm}^{3}$. Uptake of ${ }^{131} \mathrm{I}$ in the $24^{\text {th }}$ hour ranged from $9.5 \%$ to $30.2 \%$ (mean: $17.1 \%$ ).

Symptoms of thyrotoxicosis (palpitation and tremors) were reported by two $(5.5 \%)$ patients in the first week after radioiodine treatment, but they were transient and did not require specific treatment or hospital admission. There was no case of arrhythmia after treatment. Laboratory tests revealed elevated free T4 in four (11\%) patients in the first week after therapy, but total T3 was elevated in only two of these patients. Free T4 and total $\mathrm{T} 3 \mathrm{r}$ returned to normal in all four patients one month after radioiodine administration.

One year after radioiodine therapy, $\mathrm{SCH}$ was resolved in $30(83.3 \%)$ patients, and hypothyroidism was detected in one $(2.7 \%)$. None of the patients progressed to overt thyrotoxicosis. Six (16.6\%) patients continued to present $\mathrm{SCH}$, but hyperfunction improved in three of these patients, with TSH increasing from $\leq 0.1$ $\mathrm{mIU} / \mathrm{L}$ to $0.2,0.22$, and $0.3 \mathrm{mIU} / \mathrm{L}$, respectively.

Twelve of the 17 women evaluated before and one year after radioiodine therapy were euthyroid. In the patients in whom thyroid function returned to normal, femoral BMD increased by $1.9 \%$, and lumbar spine BMD by $1.6 \%$, in average. In addition, there was a significant decrease of serum CTx levels [mean of $45 \%, \mathrm{p}$ $<0.01]$, but no significant change in serum osteocalcin concentration was observed. Four women continued to present SCH. In these patients, BMD decreased by $2 \%$ in the femur and by $1.8 \%$ in the lumbar spine, in average. No changes in serum osteocalcin or CTx were observed.

\section{DISCUSSION}

A high rate of resolution (83.3\%) of hyperthyroidism was achieved in the present study. This success rate, even with an activity of $15 \mathrm{mCi}$, can be explained by the population studied, i.e., a predominance of women $>40$ years with non-voluminous goiter and mild hyperthyroidism, since all of these factors are known predictors of a better response to radioiodine (10). Although a long-term increase is possible, the rate of hypothyroidism seen in the first year $(3 \%)$ was low. The administration of ${ }^{131}$ I during TSH suppression impairs or reduces uptake by normal (non-autonomous) thyroid tissue, decreasing the risk of hypothyroidism. Some observations support this hypothesis. First, in Graves' disease, in which the whole gland takes up iodine, the frequency of hypothyroidism in the first year is high, ranging from $55 \%$ to $80 \%(14,15)$. Second, patients with toxic nodular disease who receive ${ }^{131} \mathrm{I}$ in the presence of detectable levels of TSH show higher rates of hypothyroidism than those with undetectable TSH at the time of treatment $(3,4)$. Finally, the administration of rhTSH before ${ }^{131}$ I therapy to patients with nodular disease, which increases the tissue area that takes up iodine, notably increases the risk of hypothyroidism (16). Thus, normalization of TSH with ATDs before radioiodine, restoring the uptake by normal thyroid tissue, increases the risk of hypothyroidism. However, many authors do not consider hypothyroidism an undesirable effect of radioiodine treatment since the main objective of therapy, i.e., reversal of thyrotoxicosis, is achieved.

During ${ }^{131}$ I therapy of elderly patients with clinical hyperthyroidism, prior thyroid function compensation (normalization of T4 and T3) with ATDs should be 
considered to reduce the risk of exacerbation of thyrotoxicosis, which can have important clinical consequences in these patients (1). This risk appears to be very low in $\mathrm{SCH}$, and compensation (normalization of TSH) before ${ }^{131}$ I does not seem to be necessary (1). On the other hand, administration of beta-blockers is recommended since, as observed for patients with clinical thyrotoxicosis, these drugs minimize the symptoms in patients with $\mathrm{SCH}$ who develop exacerbation of thyrotoxicosis after radioiodine ( 1 ). The use of beta-blockers may explain the absence of important symptoms in the present patients, even in those who showed transient increase of thyroid hormone levels after radioiodine treatment. Therefore, preparation with beta-blockers before ${ }^{131} \mathrm{I}$ therapy seems to be sufficient in $\mathrm{SCH}$, even in the case of elderly patients and TSH $\leq 0.1 \mathrm{mIU} / \mathrm{L}$.

With respect to the effect of TSH normalization on $\mathrm{BMD}$, the present study showed an increase of both femoral and lumbar spine BMD in as early as the first year, in agreement with the findings of Faber and cols. (8) after treatment of SCH with ${ }^{131} \mathrm{I}$. Muddle and cols. (7) also observed an increase of distal forearm BMD after treatment of SCH with methimazole. In addition to the increase in BMD seen in treated patients, BMD loss was observed in patients who did not receive treatment (8), a finding that supports the beneficial effect of this therapy. This effect seems to be the consequence of reduced bone resorption, since plasma CTx levels were also significantly decreased. No significant change in serum osteocalcin after TSH normalization was observed in the present investigation or in a previous study (7), supporting the point of view that the increase in BMD was indeed due to reduced bone resorption. Finally, it should be emphasized that all of these studies involved postmenopausal women with endogenous SCH due to nodular disease and TSH $\leq$ $0.1 \mathrm{mIU} / \mathrm{L}$ (7, present study), or $<0.2 \mathrm{mIU} / \mathrm{L}(8)$, and the results, therefore, cannot be readily extrapolated to men, premenopausal women, patients with SCH whose TSH levels are only slightly reduced, or elderly patients with low TSH and no structural thyroid disease. For example, Yonem and cols. (9) found no increase in BMD in premenopausal women after 6 months of treatment with ATDs.

The present results suggest that ${ }^{131}$ I therapy not preceded by ATDs in elderly patients with $\mathrm{SCH}$ and non-voluminous goiter is, in fact, safe, effective, and associated with low rates of short-term hypothyroidism. In addition, resolution of $\mathrm{SCH}$ seems to have be- neficial effects on bone mass in postmenopausal women with osteopenia.

Disclosure: no potential conflict of interest relevant to this article was reported.

\section{REFERENCES}

1. Bahn Chair RS, Burch HB, Cooper DS, Garber JR, Greenlee MC, Klein I, et al. Hyperthyroidism and other causes of thyrotoxicosis: management guidelines of the American Thyroid Association and American Association of Clinical Endocrinologists. Thyroid. 2011;21:593-646.

2. Rosario PW. Natural history of subclinical hyperthyroidism in elderly patients with TSH between 0.1 and $0.4 \mathrm{mIU} / \mathrm{l}$ : a prospective study. Clin Endocrinol (Oxf). 2010;72:685-8.

3. Pedersen-Bjergaard $U$, Kirkegaard C. Relationship between serum TSH and the responsiveness of toxic solitary autonomous thyroid nodules to radioiodine therapy. Eur J Endocrinol. 1998;139:587-90.

4. Pedersen-Bjergaard U, Kirkegaard C. Serum TSH and the response to radioiodine treatment of toxic multinodular goitre. Eur $\mathrm{J}$ Endocrinol. 1997;137:365-9.

5. Walter MA, Briel M, Christ-Crain M, Bonnema SJ, Connell J, Cooper DS, et al. Effects of antithyroid drugs on radioiodine treatment: systematic review and meta-analysis of randomised controlled trials. BMJ. 2007;334:514.

6. Rosario PW. Bone and heart abnormalities of subclinical hyperthyroidism in women below the age of 65 years. Arq Bras Endocrinol Metabol. 2008;52:1448-51.

7. Muddle $\mathrm{AH}$, Houben AJ, Nieuwenhuijzen Kruseman AC. Bone metabolism during anti-thyroid drug treatment of endogenous subclinical hyperthyroidism. Clin Endocrinol (Oxf). 1994;41:421-4.

8. Faber J, Jensen IW, Petersen L, Nygaard B, Hegedus L, Siersbaek-Nielsen K. Normalization of serum thyrotropin by mean of radioiodine treatment in subclinical hyperthyroidism: effect of bone loss in postmenopausal women. Clin Endocrinol (Oxf). 1998;48:285-90.

9. Yonem O, Dokmetas HS, Aslan SM, Erselcan T. Is antithyroid treatment really relevant for young patients with subclinical hyperthyroidism? Endocr J. 2002;49:307-14.

10. Allahabadia A, Daykin J, Sheppard MC, Gough SC, Franklyn JA. Radioiodine treatment of hyperthyroidism-prognostic factors for outcome. J Clin Endocrinol Metab. 2001;86:3611-7.

11. Klein I, Trzepacz PT, Roberts M, Levey GS. Symptom rating scale for assessing hyperthyroidism. Arch Intern Med. 1988;148:387-90.

12. Rosen CJ, Abrams SA, Aloia JF, Brannon PM, Clinton SK, Durazo-Arvizu RA, et al. IOM committee members respond to Endocrine Society vitamin D guideline. J Clin Endocrinol Metab. 2012;97:1146-52.

13. Aloia JF. Clinical Review: The 2011 report on dietary reference intake for vitamin D: where do we go from here? J Clin Endocrinol Metab. 2011;96:2987-96.

14. Alexander EK, Larsen PR. High dose of (131)I therapy for the treatment of hyperthyroidism caused by Graves' disease. J Clin Endocrinol Metab. 2002;87:1073-7.

15. Andrade VA, Gross JL, Maia AL. The effect of methimazole pretreatment on the efficacy of radioactive iodine therapy in Graves' hyperthyroidism: one-year follow-up of a prospective, randomized study. J Clin Endocrinol Metab. 2001;86:3488-93.

16. Fast $S$, Nielsen VE, Grupe P, Boel-Jørgensen H, Bastholt L, Andersen PB, et al. Prestimulation with Recombinant Human Thyrotropin (rhTSH) improves the long-term outcome of radioiodine therapy for multinodular nontoxic goiter. J Clin Endocrinol Metab. 2012;97:2653-60. 